\title{
Significant Learning In University Students From The Area Of Financial Accounting Through The Use Of A WebQuest
}

Adelaida Ciudad-Gómez, University of Extremadura, Spain Jesús Valverde-Berrocoso, University of Extremadura, Spain

\begin{abstract}
The use of Information \& Communication Technologies and active learning methodologies are among the main challenges faced at university level in the new European Higher Education Area (EHEA), which promotes a learning process in which the student becomes a proactive subject in their own education.

One of these methodologies is what is known as a WebQuest, a system that allows to integrate ICT in web-based research and problem-solving activities, thereby fostering collaborative work.

The purpose of this project was to describe a teaching experience on the use of WebQuest in a university setting, in the field of Financial Accounting and as part of a training and skillsassessment model known as MANagement of COMpetence in the areas of Accounting (MANCOMA).
\end{abstract}

Keywords: WebQuest; Financial Accounting; Competence; Constructivism; Higher Education

\section{INTRODUCTION}

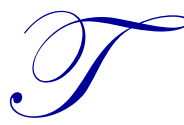

he use of Information \& Communication Technologies and active learning methodologies are among the main challenges faced at university level in the new European Higher Education Area (EHEA). One of these methodologies is WebQuest (WQ), which has been extensively implemented in recent years in various educational settings. It was created by Bernie Dodge, on the basis of the model defined by Feuerstein et al. (1980), which classifies the mental act in three levels: inputs - elaboration - outputs, and is based on the idea that the student will be able to build their own learning if the teacher, undertaking the role of mediator, provides them with the scaffolding they need, as this will enable them to carry out learning activities that require cognitive processes of a higher order.

The WebQuest was defined by Dodge (1997) as "an inquiry-oriented activity in which some or all of the information that learners interact with comes from resources on the internet" and is characterized by what Dodge (2001) describes as deep learning that involves constructing new knowledge through a critical thinking process.

In turn, Zheng et al. (2008, p. 297) adds that studies show that the WebQuest is supported by four underlying constructs: critical thinking, knowledge application, social skills and scaffolded learning (e.g., Dodge, 1995, 2001; Pohan \& Mathison, 1998; Brucklacher \& Gimbert, 1999; Vidoni \& Maddux, 2002).

According to Weinstein (2000), critical thinking consists of six key elements: (a) skillful thinking, (b) responsible thinking, (c) non-routine thinking, (d) applying criteria, (e) self-correction and (f) sensitivity, while Vidoni \& Maddux (2002, p. 101) concludes that "WebQuests meet all six of Weinstein's key elements in critical thinking and therefore are powerful tools for inspiring critical thinking skills in students." 
Students' ability to apply what they have already learned to new learning is an important component in WebQuests according to Pohan \& Mathison (1998). This opinion coincides with Brucklacher \& Gimbert (1999) in that the application of knowledge fosters association, promotes knowledge and significant, deep learning.

As regards social skills, Dodge $(2001$, p. 8 ) holds that the theory of cooperative learning emphasises positive interdependence, individual and group responsibility, as well as the interpersonal skills of the small group in learning, claiming that "A well-orchestrated WebQuest has these qualities as well."

Finally, studies also demonstrate that scaffolding has a positive effect on student achievement (Scardamalia et al., 1984; Lim et al., 2001; Baylor, 2002, Cho \& Jonassen, 2002), which is defined by Dodge (2001, p. 58) as "a temporary structure used to help learners act more skilled than they really are" and proposes to use them at three key moments: when receiving information, transforming information and producing information.

Therefore, we designed a WebQuest, included within our model of the competency-based teaching and assessment, envisaged in the "Financial Accounting III" in the "Degree in Business Administration and Management", and called "MANagement of COMpetence in the areas of Accounting (MANCOMA)" (Ciudad \& Valverde, 2012).

\section{DESCRIPTION OF EXPERIENCE}

The purpose of using WebQuest in "ACTIVITY-5 WebQuest: Adjusting Entries, Financial Statement Preparation \& Interpret the Financial Information" was to employ a tool that would allow students to work on an independent and cooperative basis, while also improving students' learning achievements in terms of skills rather than knowledge, in a bid to foster significant, deep learning.

In order to ensure that we would achieve our goal, we set up a WebQuest with a clearly defined layout, structured in the following sections: Welcome, Introduction, Task, Process, Resources, Evaluation, Conclusion and Teacher Page; paid special attention to the Process and Evaluation sections, because, as Lara (2006, p. 440) points out, "scaffolding is a very important element in WebQuest and the instructions provided in the 'process' and 'evaluation' sections guide the student to work independently on the set task." According to Dodge (2000), there are three different types of scaffolding: reception, transformation, and production.

The Process section gives the student an outline that includes assistance and complementary information in every section of the process to be followed, giving them a production scaffolds that will have a positive effect on their achievement (Scardamalia et al., 1984; Lim et al., 2001; Baylor, 2002, Cho \& Jonassen, 2002).

As regards the assessment of the proposed activity, we used two evaluation rubrics. The advantages of this are (Pickett \& Dodge, 2007):

- Evaluation is more objective and consistent. In this regard, various researchers have indicated that the evaluation carried out by the teaching staff is more reliable if the rubrics are used (Johnsson \& Svingby, 2007; Silvestri \& Oescher, 2006).

- It obliges the professor to clarify their criteria in specific terms.

- It clearly shows the student what is expected of them and how their work will be evaluated.

- It gives the student an awareness of the criteria used to assess the performance of their classmates.

- It provides useful feedback on the effect of teaching.

- It provides indicators that are useful for evaluating and documenting students' progress.

We also used them to propose self-assessment and peer evaluation, involving the students in their own assessment in order to contribute towards a better understanding of the learning process and, in short, towards greater autonomy and self-regulation for the student (Stevens \& Levi, 2005).

Following the theories of Dodge (2001) and as complementary features, our WebQuest was addressed as a group activity. The point of departure for this was that learning in a group is more efficient than individual learning 
in terms of academic performance (Johnson \& Johnson, 1974; Slavin, 1985; Johnson et al., 1988). It was presented with a motivational element, giving the student the role of accountant in a company, where the administrative manager asks them for help. The activity is also proposed in "Financial Accounting III," but the student needs to apply all of the knowledge previously acquired in "Financial Accounting I" and "Financial Accounting II."

Finally, it should be pointed out that this activity was initially designed as a website with the use of an HTML editor. Then it was changed into a SCORM package, which enabled us to add it to our virtual classroom (Moodle), as well as a consultation that was added so that students could form work teams and a forum so that they could inform as to who was appointed as the group coordinator.

\section{CONCLUSIONS}

The aim of using WebQuest methodology in our subject is to improve our students' learning results (Valverde, 2008). Although there are studies that demonstrate that that they do not usually represent a significantly differential advantage over other teaching methods, if the learning results are measured in terms of knowledge acquired, they are convinced that it is a very appropriate method when the results do not focus solely on the acquisition of concepts but also on skills, abilities, values and attitudes, all of which are components of the competencies to be developed.

This methodology has also allowed us to implement directed, self-regulated learning. Together with the rubrics, this has become a suitable tool for providing useful feedback to students and enabling self-assessment and peer-assessment, thereby contributing towards greater autonomy among students.

As regards the drawbacks, one is the high number of students per group. Because the use of active methodologies allows and requires more fluid communication between professor and students, the professor has to devote more time to directing the student than they would in more traditional teaching methodologies. This means that if it is to be applied, the group sizes should be smaller if we wish to avoid a drop in quality.

Looking ahead, we propose that the application of this methodology be extended to other subjects and qualifications. Information should be gathered for analysis regarding the impact of this methodology on learning results, as well as the students' perception of the roll-out of WebQuest methodology and the use of the rubric as an evaluation tool.

\section{AUTHOR INFORMATION}

Adelaida Ciudad-Gomez holds a Degree in Business Administration from the University of Sevilla and is a Professor in the Accounting and Finance Department, Faculty of Business Studies and Tourism of Cáceres at the University of Extremadura, Spain. Adelaida's research interests include accounting, educational, tourism and environment. E-mail: adelaida@unex.es (Corresponding author)

Jesús Valverde-Berrocoso holds a PhD in Pedagogy from the University of Salamanca and is a Professor in the Sciences Education Department, Faculty of Teacher Education at the University of Extremadura, Spain. He is currently Director of the Virtual Campus of the University of Extremadura (CVUEX) and Director of Shared Virtual Campus G9 Group of Universities (CVC-G9). His research interests include ICT in education; e-learning in higher education; instructional design and technology.

\section{REFERENCES}

1. Baylor, A. L. (2002). Expanding preservice teachers' metacognitive awareness of instructional planning through pedagogical agents. Educational Technology Research and Development, 50(2), 5-22. Retrieved January 2013 from http://www.speakeasydesigns.com/SDSU/student/SAGE/compsprep/Instructional_Planning_through_Peda gogical_Agents.pdf 
2. Brucklacher, B., \& Gimbert, B. (1999). Role-playing software and WebQuests-what's possible with cooperative learning and computers. Computers in the Schools, 15(2), 37-48.

3. Cho, K. L., \& Jonassen, D. H. (2002). The effects of argumentation scaffolds on argumentation and problem solving. Educational Technology Research and Development, 50(3), 5-22. Retrieved January 2013 from http://www.speakeasydesigns.com/SDSU/student/SAGE/compsprep/Argumentation_and_Problem_Solving .pdf

4. Ciudad, A., \& Valverde, J. (2012). Design of a competency-based assessment model in the field of Accounting. Contemporary Issues in Education Research, 5(5), 343-348. Retrieved December 2012 from http://journals.cluteonline.com/index.php/CIER/article/view/7466/7532

5. Ciudad, A. (2011). Design of the accounting course focusing on the development of competences. Journal of International Education Research, 7(5), 15-22. Retrieved January 2012 from http://journals.cluteonline.com/index.php/JIER/article/view/6112/6190

6. Dodge, B. (1995). WebQuests: A technique for Internet-based learning. Distance Educator, 1(2), $10-13$.

7. Dodge, B. (1997). Some thoughts about webquests. Retrieved December 2012 from http://webquest.sdsu.edu/about_webquests.html

8. $\quad$ Dodge, B. (2000). Thinking visually with WebQuests [Online]. Presentation at the National Educational Computing Conference, Atlanta, GA. Retrieved February 2013 from http://edweb.sdsu.edu/WebQuest/tv/

9. Dodge, B. (2001). FOCUS: Five rules for writing a great WebQuest. Learning and Leading With Technology, 28(8), 6-9. Retrieved February 2013 from http://webquest.sdsu.edu/focus/focus.pdf

10. Feuerstein, R., Rand, Y., Hoffman, M. B., \& Miller, R. (1980). Instrumental enrichment. Baltimore: University Park Press.

11. Johnson, D. W., \& Johnson, R. T. (1974). Instructional goal structure: Cooperative competitive or individualistic. Review of Education Research, 44, 213-240.

12. Johnson, D. W.; Johnson R. T., \& Smith, K. A. (1998). Cooperative learning returns to college: What evidence is there that it works? Change, 20(4), 26-35. Retrieved December 2012 from http://www.ce.umn.edu/ smith/docs/CLReturnstoCollege.pdf

13. Jonsson, A., \& Svingby S. (2007). The use of scoring rubrics: Reliability, validity and educational consequences. Educational Research Review, 2, 130-144 Retrieved January 2013 from https://facultycommons.macewan.ca/wp-content/uploads/Rubrics-Jonasson-and-Svingby-20071.pdf

14. Lara, S. (2006). Estudio de la eficacia de la WebQuest para fomentar el aprendizaje activo en alumnos universitarios. In Comunicación presentada en el IV International Conference on Multimedia and Information and Communication Technologies in Education (m-ICTE2006). Sevilla (Spain) Volume I: General Issues, Pedagogical Issues (pp. 437-441). Retrieved February 2013 from http://grupohada.wikispaces.com/file/view/Eficiencia+de+la+WebQuest+para+fomentar+el+aprendizaje+a ctivo.pdf

15. Lim, B. R., Plucker, J. A., \& Nowak, J. A. (2001). We are what we weave? Issues and guidelines for learning by web design. Educational Technology, 41(6), 23-27.

16. Pohan C., \& Mathison C. (1998). WebQuests: the potential of Internet-absed instruction for global education. Social Studies Review, 37, 91-93.

17. Scardamalia, M., Bereiter, C., \& Steinbach, R. (1984). Teachability of reflective processes in written composition. Cognitive science, 8(2), 173-190. Retrieved January 2013 from http://csjarchive.cogsci.rpi.edu/1984v08/i02/p0173p0190/MAIN.PDF

18. Silvestri, L., \& Oescher, J. (2006). Using rubrics to increase the reliability of assessment in health classes. International Electronic Journal of Health Education, 9, 25-30.

19. Slavin, R. (1985). Learning to cooperate, cooperating to learn. Nueva York: Plenum Press.

20. Stevens, D. D., \& Levi, A. (2005). Introduction to rubrics: An assessment tool to save grading time, convey effective feedback, and promote student learning. Stylus Pub Llc.

21. Valverde, J. (2008). Webquest como estrategia metodológica en entornos virtuales de aprendizaje de Educación Superior: evaluación de una experiencia. En M.E. Del Moral y R. Rodríguez, Experiencias docentes y TIC (pp. 129-149). Barcelona: Octaedro.

22. Vidoni K., \& Maddux C. (2002). WebQuests: Can they be used to improve critical thinking skills in students? Computers in the Schools, 19, 101-117.

23. Weinstein, M. (2000) A framework for critical thinking. High School Magazine, 7, 40-43. 
24. Zheng, R., Perez, J., Williamson, J., \& Flygare, J. (2008). WebQuests as perceived by teachers: implications for online teaching and learning. Journal of Computer Assisted Learning, 24, 295-304. Retrieved December 2012 from http://internationalprofessor.com/UNMS/webquest.pdf 
NOTES 